Article

\title{
Studying Hydraulic Interconnections in Low-Permeability Media by Using Bacterial Communities as Natural Tracers
}

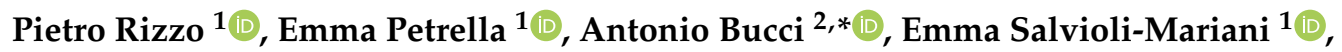 \\ Alessandro Chelli ${ }^{1}$, Anna Maria Sanangelantoni ${ }^{1}$, Melinda Raimondo ${ }^{1}$, Andrea Quagliarini ${ }^{1}$ \\ and Fulvio Celico ${ }^{1}$ (D) \\ 1 Department of Chemistry, Life Sciences and Environmental Sustainability, University of Parma, Parco Area \\ delle Scienze 157/A, 43124 Parma, Italy; pietro.rizzo2@studenti.unipr.it (P.R.); emma.petrella@unipr.it (E.P.); \\ emma.salviolimariani@unipr.it (E.S.-M.); alessandro.chelli@unipr.it (A.C.); \\ annamaria.sanangelantoni@unipr.it (A.M.S.); melinda.raimondo@studenti.unipr.it (M.R.); \\ andrea.quagliarini15@gmail.com (A.Q.); fulvio.celico@unipr.it (F.C.) \\ 2 Department of Biosciences and Territory, University of Molise, C. da Fonte Lappone, 86090 Pesche, Italy \\ * Correspondence: antonio.bucci@unimol.it; Tel.: +39-0874-404156
}

Received: 2 June 2020; Accepted: 19 June 2020; Published: 23 June 2020

\begin{abstract}
Knowledge about the processes governing subsurface microbial dynamics in and to groundwater represents an important tool for the development of robust, evidence-based policies and strategies to assess the potential impact of contamination sources and for the implementation of appropriate land use and management practices. In this research, we assessed the effectiveness of using microorganisms as natural tracers to analyze subsurface dynamics in a low-permeability system of northern Italy. Microbial communities were investigated through next-generation sequencing of $16 \mathrm{~S}$ rRNA gene both to study hydraulic interconnections in clayey media and to verify the efficacy of outcropping clayey horizons in protecting groundwater against contamination. During the observation period, a rapid water percolation from the ground surface to the saturated medium was observed, and the mixing between lower-salinity fresh-infiltration waters and higher-salinity groundwater determined the formation of a halocline. This rapid percolation was a driver for the transport of microorganisms from the topsoil to the subsurface, as demonstrated by the presence of soil and rhizosphere bacteria in groundwater. Some of the species detected can carry out important processes such as denitrification or nitrate-reduction, whereas some others are known human pathogens (Legionella pneumophila and Legionella feeleii). These findings could be of utmost importance when studying the evolution of nitrate contamination over space and time in those areas where agricultural, industrial, and civil activities have significantly increased the levels of reactive nitrogen (N) in water bodies but, at the same time, could highlight that groundwater vulnerability of confined or semi-confined aquifers against contamination (both chemical and microbiological) could be higher than expected.
\end{abstract}

Keywords: groundwater; soil; microbiological investigations; prokaryotes; low-permeability media

\section{Introduction}

Microorganisms are ubiquitous in the natural environment: in soils, their concentrations can be of approximately $10^{8}-10^{9}$ cells per gram [1]. While a significant majority of them carry out beneficial processes (e.g., they can play a critical role in subsurface biogeochemical cycling), some bacteria and other microorganisms (e.g., protozoa and viruses) are pathogenic, that is, they are capable of causing disease in humans [2]. 
Accordingly, studying the transport and retention of microorganisms in soil and in the underlying layers can be of interest for many reasons such as the analysis of water supplies pathogen contamination and pollutants degradation during in situ bioremediation. A range of physical, physicochemical, and biological processes may play a role in controlling the fate and transport of a microorganism once it has been introduced into the natural subsurface environment [1]. Among these, various macroscopic processes and mechanisms (e.g., advection, sedimentation, hydrodynamic dispersion, chemotaxis, motility, retention, inactivation, and growth) act on microorganisms in both saturated and unsaturated subsurface zones. Thus, knowledge of the processes governing subsurface microbial dynamics in and to groundwater represents an important tool for the development of robust, evidence-based policies and strategies to assess the potential impact of contamination sources and for the implementation of appropriate land use and management practices to protect groundwater supplies [1].

Many studies have examined physical (size of the microbe and the porous medium, microbe concentration, water velocity, water content, and surface roughness) and chemical (surface chemistry of the microbe and soil, aqueous solution $\mathrm{pH}$, ionic strength (IS), and chemical composition) factors that influence the retention of microorganisms in homogeneous porous media [3-9] through repacked column breakthrough curves (BTCs) and retention profiles (RPs), batch experiments, and complementary micromodel studies allowing direct microscopic observation [10].

In this research, we evaluated the effectiveness of microorganisms as natural tracers of subsurface dynamics in a low-permeability system of northern Italy by using next-generation sequencing (NGS) of the 16S rRNA gene, one of the most widely used applications for the taxonomic and phylogenetic evaluation of microbial community composition [11,12].

Generally, tracing techniques have demonstrated particular usefulness in hydrogeology. They represent powerful investigative tools which allow quantification of transport parameters and measurement of subsurface properties in a way often unmatched by standard physical methods. Furthermore, tracer tests directly measure properties in situ and can be used to investigate very specific processes by selecting tracers with appropriate physicochemical properties. Most of the groundwater tracers used for hydrogeological purposes are chemicals and isotopic; they are used to determine the water origin, groundwater directions, velocities of subsurface flow, etc. Nonetheless, these more commonly used tracers can also have some drawbacks. For example, one obstacle to the use of environmental tracers is the potential lack of information on the input function, whereas artificial tracers pose the problem of the introduction of undesirable substances into groundwater resources. On the other hand, the migration of bacterial cells through natural clayey media has been studied mostly at the laboratory scale through column tests [13-16].

Microbial communities, which are greatly influenced by the physicochemical features of the environment in which they live, have been proven to be excellent tracers in some hydrogeological scenarios, allowing the analysis of complex phenomena. The efficacy of using microorganisms for specific hydrogeological purposes has been verified in recent researches [17-19], concerning recharge processes in karst environments, flow processes in compartmentalized aquifer systems [20,21], mixing processes between deep and shallow fluids in hydrothermal systems [22], mixing processes between groundwater and seawater in coastal aquifers [22,23], and mixing processes between brines and groundwater in evaporates bearing low-permeability successions.

\section{Materials and Methods}

\subsection{Test Site}

The test site is located within the Taro River valley (Italian northern Apennines; Figure 1). The local geological sequence (belonging to the Ligurian Domain of the northern Apennines [24]), can be described as follows (from top to bottom): (i) Arenarie di Scabiazza (SCB) is made up of thin layers of clay stone alternating with layers of sandstones and marls; (ii) Argillle a Palombini di Monte Rizzone (AMR) is made up of clay stones and limestone; locally, SCB lies directly on the underlying 
Ottone tectonic unit that is made of clay stones containing clasts and blocks of limestone (Argille a blocchi, $\mathrm{CCVb}$ ); and (iii) the latter lies directly (tectonic boundary) on the underlying Flysch of Monte Caio (CAO) made of marly-limestones turbidites and argillites.

At the test site, where groundwater and soil samples were collected for microbial community investigations, a matrix-supported deposit characterized by a clay-silty matrix was detected from the ground surface to about $31 \mathrm{~m}$ below ground level (b.g.1.). From $31 \mathrm{~m}$ to $34 \mathrm{~m}$ b.g.l., the rocks are clast-supported and poorer in the matrix. The top of the bedrock was detected at $35 \mathrm{~m}$ b.g.l. [25]. Four falling-head tests were carried out at different depths to estimate the hydraulic conductivity of the clayey medium $\left(1.9 \times 10^{-9}\right.$ to $\left.3.3 \times 10^{-8} \mathrm{~m} / \mathrm{s}\right)$ and confirmed its expected low permeability.

The local land use can be classified as permanent grassland. The soil medium is characterized [25] by $\mathrm{pH}$ values ranging from neutral to moderately alkaline and high percentage of Soil Organic Matter (SOM; about 19\%). As observed by Remelli et al. [25], high SOM is further confirmed by the presence of arthropods of the order Diptera [26] and the class Symphyla [27]. However, the soil arthropod abundance detected by Remelli et al. [25] was lower than a typical grassland condition [28], therefore suggesting a stressful action that dramatically affected the study site.

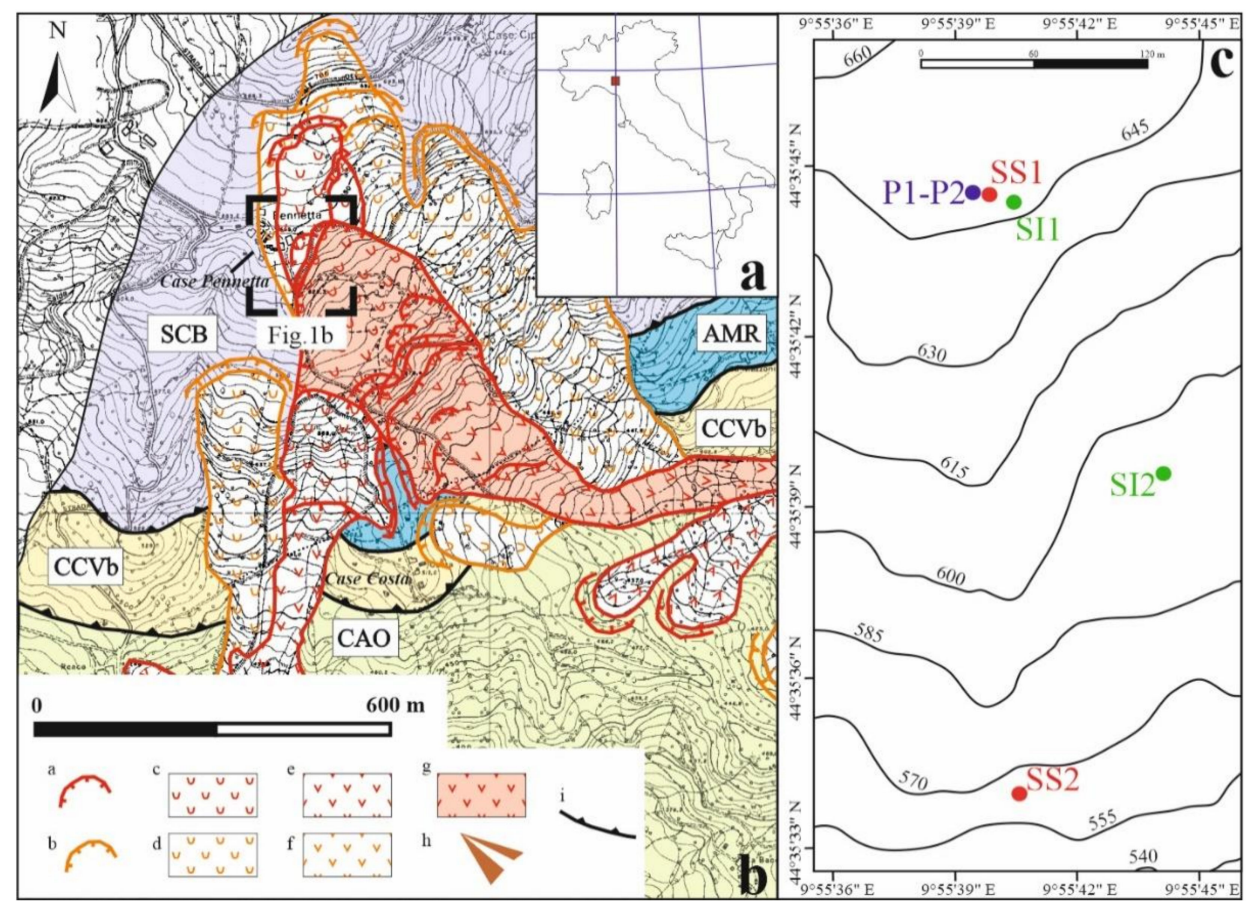

Figure 1. (a) Localization of the study area and (b) geological and geomorphological sketch map of the study area: (a) scarp of active landslide, (b) scarp of dormant landslide, (c) active landslide, (d) dormant landslide, (e) active earth flow, (f) dormant earth flow, (g) active earth slide/earth flow, (h) debris/earth flows cone with man interventions, and (i) main thrust. SCB: Arenarie di Scabiazza (sandstone); AMR: Argillle a Palombini di Monte Rizzone (clay stone); CCVb: Argille a blocchi (clay stone with blocks); CAO: Flysch of Monte Caio (marly-limestone). Base map: Technical Regional Map 1:5000, Emilia-Romagna Region 1998 (ed.) [29]. (c) Detailed topographic map with the location of boreholes (SI1-SI2), piezometers (P1-P2), and soil sample collection sites (SS1-SS2).

\subsection{Mineralogical Investigations}

Mineralogical analyses were performed on four soil samples collected at two different locations within the study site (SI1 and SI2 in Figure 1) during the drilling operations of two boreholes. The samples, taken at depths of 10.30-10.60 m and 16.50-17.00 m at SI1 and of 6.70-7.30 m and $8.20-8.80 \mathrm{~m}$ at SI2, were manually crushed with an agate mortar until the material passed a 230 mesh 
sieve. The obtained powder was subjected to sonication in distilled water with an ultrasonic probe to obtain a homogeneous dispersion.

The clay fraction of $<2 \mu \mathrm{m}$ was separated by gravitational settling in a column of water $10 \mathrm{~cm}$ high. Oriented preparations (obtained by sedimentation on glass slides) were used for X-ray diffraction under three different states: air-dried, after saturation with ethylene glycol, and heated at $550{ }^{\circ} \mathrm{C}$.

X-ray diffraction was performed by using a Bruker D2 PHASER diffractometer (Billerica, MA, USA) with $\mathrm{Cu} \mathrm{K} \alpha$ radiation $(\lambda=1.5406 \AA$ ), under operating conditions of $30 \mathrm{kV}$ and $10 \mathrm{~mA}, \mathrm{Ni}$ filtered, and angle $2 \theta$ in the range $5-60^{\circ}$, with steps of $0.02^{\circ}$ and a collecting time for each step of $1 \mathrm{~s}$. The diffractometer has a $\theta-\theta$ focalizing geometry and a solid-state detector. A sample rotation of $30 \mathrm{rpm}$ was applied to minimize crystal preferential orientation effects. The diffraction patterns were identified using the Bruker software EVA and the Crystallography Open Database.

\subsection{Hydrogeological Investigations}

The hydraulic head was measured in P1 (see location in Figure 1) in high flow, and head fluctuations were compared with local precipitations. The groundwater Electrical Conductivity (EC) was measured both in P1 and P2 during the same observation period. P1 is a 25-meter-deep piezometer, screened between 1 and 24 meters b.g.l., while the piezometer P2 is 35 meters deep and has been screened between 30 and 34 meters b.g.l. They are part of a multilevel groundwater monitoring system (cluster type).

The hydraulic head was measured on an hourly basis through a pressure transducer with data-logger (STS DL.OCS/N/RS485, Sirnach, Switzerland) from 04/07/2018 to 15/01/2019. The reliability of the measurements was verified monthly by using a water level meter.

EC vertical profiles were obtained on a monthly basis from 15/11/2018 to 15/01/2019 by using a borehole probe (SOLINST TLC, Georgetown, ON, Canada). Measurements were carried out at 1 -m-depth intervals. The reliability of EC values was always verified through laboratory analyses. Groundwater EC measurements were carried out in order to verify the presence of haloclines and the chance to use them for the investigation of the hydrogeological behavior of the analyzed system [30-32].

\subsection{Next-Generation Sequencing (NGS) for Bacterial Community Analyses}

Bacterial community analyses were performed on three groundwater (GWS1, GWS2, and GWS3; $1 \mathrm{~L}$ each) and two soil samples (SS1 and SS2; $0.5 \mathrm{~g}$ each) collected within the test site.

Groundwater sample collection occurred once in the high-flow period at the two piezometers. GWS1 was taken immediately below the hydraulic head in P1 through sterile bailers, whereas GWS2 was collected at the well bottom through a stainless-steel bailer fitted with a one-way valve at the lower end and attached to 6-mm plastic tubing at the upper end. The upper end of the tubing was attached to a pump. The bailer was pressurized with air before, lowering it to the chosen sampling depth. At the chosen depth, the pressure was released, allowing water to enter the bailer. After the bailer was withdrawn, water was transferred to a sterile bottle. GWS3 was sampled in P2 at the well bottom with the same procedure described above.

One soil sample (SS1) was collected very close to the piezometers P1 and P2, while the other (SS2) was taken at a greater distance (Figure 1). Soils were stored in sterile vials and were transported in refrigerated boxes, together with the water samples, to the laboratory for subsequent biomolecular analyses.

Water samples were filtered through sterile mixed esters of cellulose filters (S-Pak ${ }^{\mathrm{TM}}$ Membrane Filters, $47 \mathrm{~mm}$ diameter, $0.22 \mu \mathrm{m}$ pore size, Millipore Corporation, Billerica, MA, USA) within $24 \mathrm{~h}$ from the collection. Bacterial DNA extraction from filters was performed using the commercial kit FastDNA SPIN Kit for soil (MP Biomedicals, LLC, Solon, OH, USA) and FastPrep®Instrument (MP Biomedicals, LLC, Solon, OH, USA). After the extraction, DNA integrity and quantity were evaluated by electrophoresis in $0.8 \%$ agarose gel containing $1 \mu \mathrm{g} / \mathrm{mL}$ of Gel-Red ${ }^{\mathrm{TM}}$ (Biotium, Inc., Fremont, CA, USA). The bacterial community profiles in the samples were generated by NGS technologies at the 
Genprobio Srl Laboratory. Partial 16S rRNA gene sequences were obtained from the extracted DNA by Polymerase Chain Reaction (PCR) using the primer pair Probio_Uni and Probio_Rev, targeting the V3 region of the bacterial 16S rRNA gene sequence [33]. Amplifications were carried out using a Veriti Thermal Cycler (Applied Biosystems, Foster City, CA, USA), and PCR products were purified by the magnetic purification step involving the Agencourt AMPure XP DNA purification beads (Beckman Coulter Genomics GmbH, Bernried, Germany) in order to remove primer dimers. Amplicon checks were carried out as previously described [33]. Sequencing was performed using an Illumina MiSeq sequencer (Illumina, Hayward, CA, USA) with MiSeq Reagent Kit v3 chemicals. The .fastq files were processed using a custom script based on the QIIME software suite [34]. Paired-end read pairs were assembled to reconstruct the complete Probio_Uni/Probio_Rev amplicons. Quality control retained sequences with a length between 140 and $400 \mathrm{bp}$ and mean sequence quality score $>20$, while sequences with homopolymers $>7 \mathrm{bp}$ and mismatched primers were omitted. To calculate downstream diversity measures, operational taxonomic units (OTUs) were defined at 100\% sequence homology using DADA2 [35]; OTUs not encompassing at least 2 sequences of the same sample were removed. All reads were classified to the lowest possible taxonomic rank using QIIME2 [34,36] and a reference dataset from the SILVA database v132 [37]. The biodiversity of the samples (alpha-diversity) was calculated with the Shannon index.

\section{Results}

\subsection{Mineralogical Investigations}

Mineralogical analyses showed the presence of significant amounts of quartz, discrete quantities of clay minerals, and subordinate plagioclase. The highest content of clay minerals was found in the sample collected at 16.50-17.00 $\mathrm{m}$ at SI1. The identified clay minerals were illite, chlorite, and irregular mixed layers illite-smectite and illite-chlorite. Illite was always characterized by a rather large and weak (002) reflection, suggesting disordered illite (1 Md polytype) and the presence of $\mathrm{Fe}^{3+}$ in the octahedral sites. Chlorite had a strong (002) reflection and a (001) reflection with very low intensity and was partially hidden by the asymmetry of the peak at about $10 \AA$ of the illite. The behavior of chlorite reflections in ethylene glycol saturated and heated preparations suggested swelling chlorite $(\mathrm{Cg})$. The asymmetry of the illite (001) reflection towards low angular values indicated the presence of irregular mixed layers with smectite (montmorillonite) and chlorite.

In samples collected at SI2 and at the topmost layer at SI1, a shoulder towards the low angular values of the (001) reflection of illite, corresponding to a d value of about $12 \AA$ and a strong increase in the illite (001) reflection in the heated sample, suggested the presence of regular mixed layers illite-montmorillonite or illite-vermiculite or both. Finally, the most superficial horizon analyzed at SI2 showed a doublet related to the (004) reflection of chlorite and the (002) reflection of kaolinite. The shape of the irregular mixed layers illite-montmorillonite suggested the presence of $\mathrm{Ca}^{2+}$ as the interlayer cation of montmorillonite.

\subsection{Hydrogeological Investigations}

The hydraulic head in P1 rapidly fluctuated during infiltration events (Figure 2), confirming the fast percolation of fresh-infiltration waters from the ground surface towards the phreatic zone observed by Remelli et al. [25] at the same site. The rapid arrival of percolation waters from the ground surface was further supported by the sharp decrease of groundwater EC measured below the hydraulic head in P1 (Figure 3), indicating a mixing process between lower-salinity fresh-infiltration waters and higher-salinity groundwater. In detail, during the observation period, a significant difference between values recorded at the bottom $(>4700 \mu \mathrm{S} / \mathrm{cm})$ and the top of the screened interval $(682$ to $1945 \mu \mathrm{S} / \mathrm{cm})$ was detected, with a step-like shape of the EC profiles. The step-like shape of the halocline is further emphasized when analyzing on the whole the EC profiles of the piezometers P1 and P2 (Figure 3). 
As a matter of fact, hydrogeological investigations suggested that the near-surface medium is characterized by porosity and permeability higher than those expected in clay-rich sediments even though no information is available concerning the possible pore-size of the rock mass within the unsaturated zone at the observation scale.

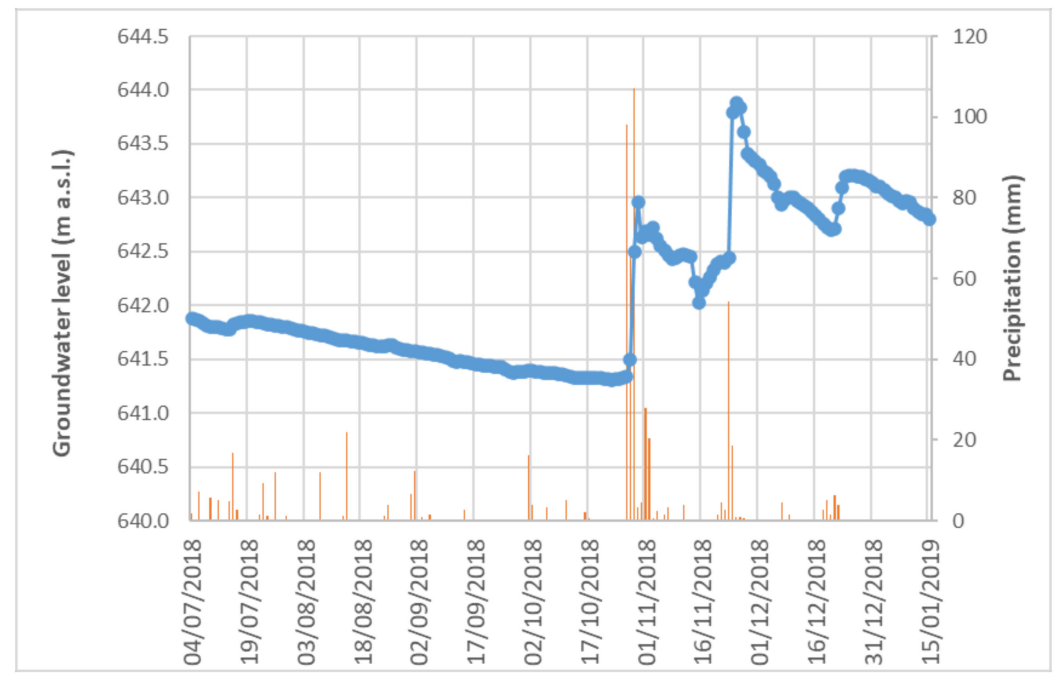

Figure 2. Groundwater level fluctuations vs rainfall in piezometer P1.

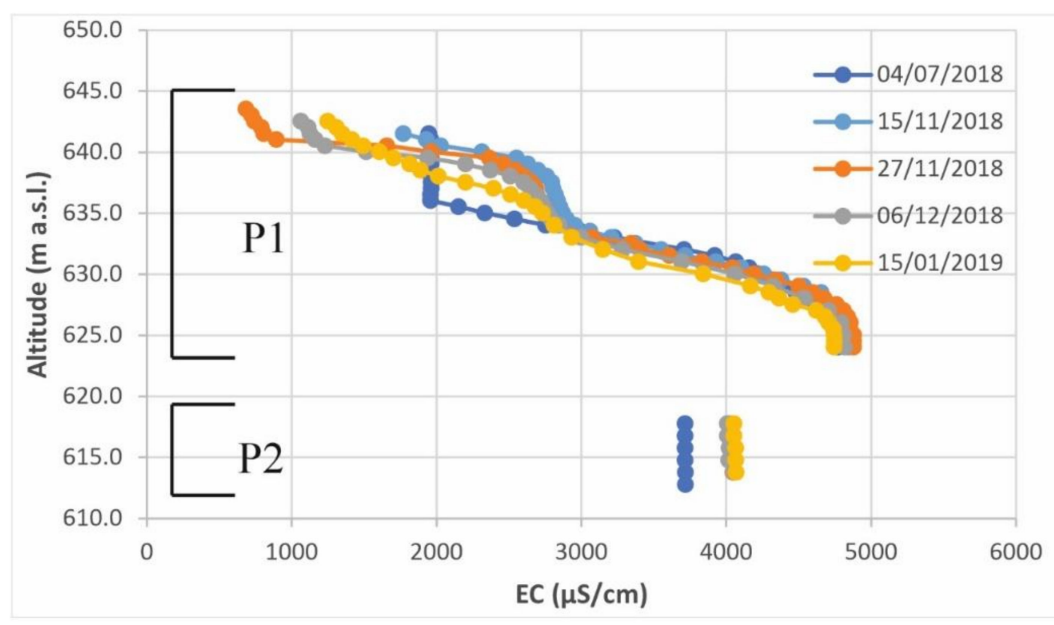

Figure 3. Vertical profile of groundwater Electrical Conductivity (EC) recorded in P1 and P2.

\subsection{Groundwater and Soil Microbial Communities}

MiSeq runs produced an average of 65,914 and 69,210 reads for groundwater (GWS1-2-3) and soil samples (SS1 and SS2), respectively (Table 1). 16S rRNA gene sequences generated in this study have been deposited in the National Center for Biotechnology Information (NCBI) Sequence Read Archive under the accession number PRJNA630902. The rarefaction analysis (a measure used to estimate the alpha-diversity in samples and to gauge whether sequencing efforts captured the microbial diversity; Figure 4) showed relatively higher biodiversity in soils (SS1 and SS2) and groundwater collected at the well bottom of the piezometer P2.

NGS results allowed to obtain detailed information about the composition of microbial communities.

Proteobacteria, Patescibacteria, Actinobacteria, and Bacteroidetes represented the four major phyla in samples GWS1 and GWS3, accounting for, on average, 57.41\%, 15.05\%, 7.52\%, and 7.11\%, respectively (Figure 5). In groundwater collected at the well bottom of the piezometer P1 (GWS2), a dominance of 
Proteobacteria (75.57\%) was observed while other phyla such as Spirochaetes (4.59\%), Nitrospirae (3.88\%), and Actinobacteria (3.83\%) occurred at lower percentages (Figure 5).

Table 1. Number of $16 \mathrm{~S}$ rDNA sequences obtained after next-generation sequencing (NGS) analysis for groundwater and soil samples.

\begin{tabular}{cc}
\hline Sample & Final Read Number \\
\hline GWS1 & 46,615 \\
GWS2 & 94,558 \\
GWS3 & 56,571 \\
SS1 & 76,569 \\
SS2 & 61,852 \\
\hline
\end{tabular}

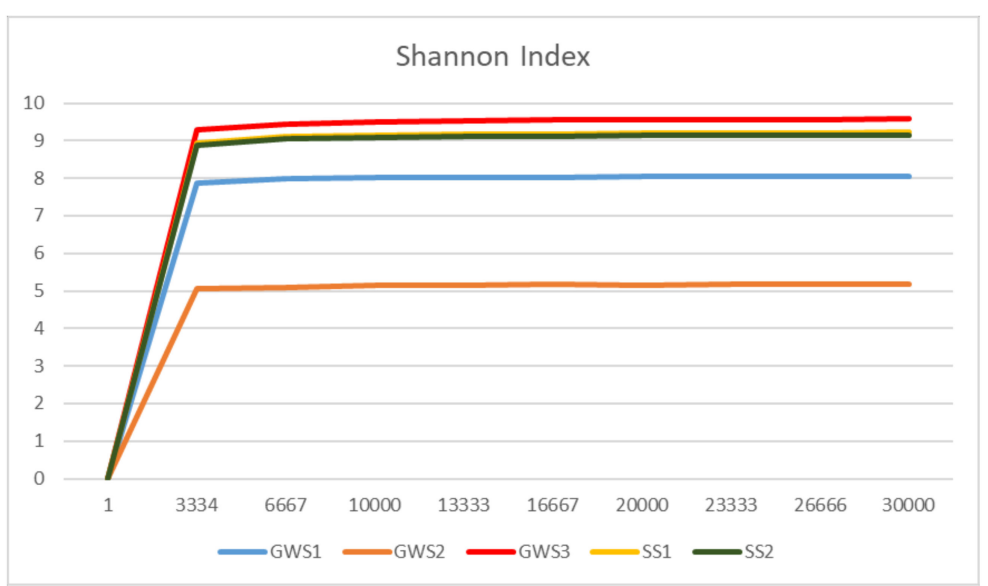

Figure 4. Rarefaction curves of groundwater and soil samples: The alpha-diversity plots were obtained by using the Shannon index.

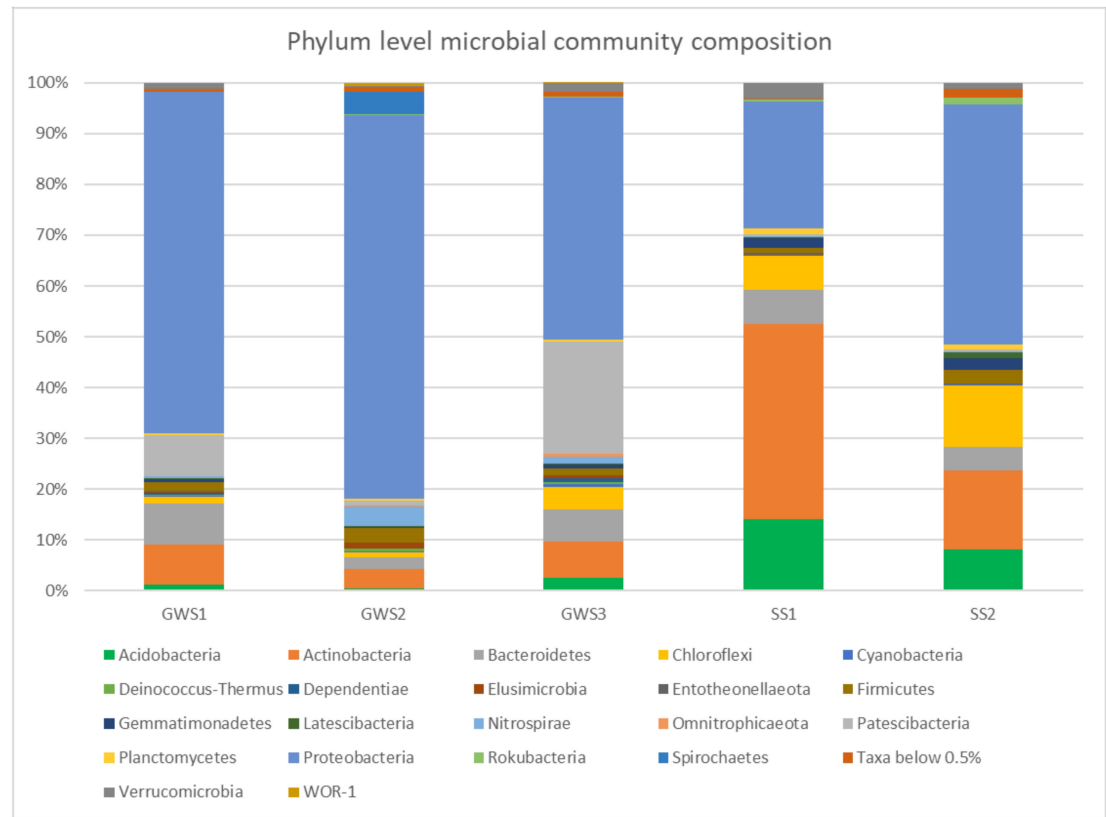

Figure 5. Phylum level microbial community composition in samples collected from groundwater and soil.

Soil bacterial communities were mainly composed of Proteobacteria, Actinobacteria, Acidobacteria, and Chloroflexi with mean relative abundance values of $36.01 \%, 27.05 \%, 11.08 \%$, and $9.39 \%$, respectively (Figure 5). 
The analysis of bacterial community composition at the family level (Figure 6) revealed, in samples GWS1 and GWS2, a predominance of Pseudomonadaceae ( $23.80 \%$ and $42.51 \%$, respectively). Among the most abundant families, Burkholderiaceae (8.49\%), Sphingomonadaceae (3.10\%), Micrococcaceae $(3.09 \%)$ and unclassified microorganisms belonging to the Saccharimonadales order (5.57\%) occurred in GWS1 whereas Desulfobacteraceae (13.28\%), Leptospiraceae (4.46\%), Thermodesulfovibrionia (3.04\%), and Desulfovibrionaceae (2.68\%) were found in GWS2.

In GWS3, unclassified microorganisms of the Saccharimonadales order represented the most numerous group $(12.37 \%)$, followed by Sphingomonadaceae $(5.21 \%)$, Burkholderiaceae $(3.98 \%)$, Acidiferrobacteraceae (3.02\%), and Legionellaceae (2.76\%).

Soil samples were characterized by high percentages of unclassified microorganisms $(29.73 \%$ in SS1 and 23.47\% in SS2). Some of these belong to the Acidobacteria (subgroup 6 class; $9.28 \%$ in SS1 and $3.80 \%$ in SS2) and Chloroflexi (1.53\% in SS1 and 1.92\% in SS2) phyla, and Gaiellales order $(4.21 \%$ in SS1 and 1.10\% SS2). Other representative families were Propionibacteriaceae (4.86\%), Gaiellaceae $(4.66 \%)$, Xanthobacteraceae (4.29\%), Nocardioidaceae (3.29\%), and Burkholderiaceae (3.10\%) in SS1 and Rhodobacteraceae (8.82\%), Halomonadaceae (3.27\%), Sphingomonadaceae (2.84\%), and Nitrosomonadaceae $(2.75 \%)$ in SS2.

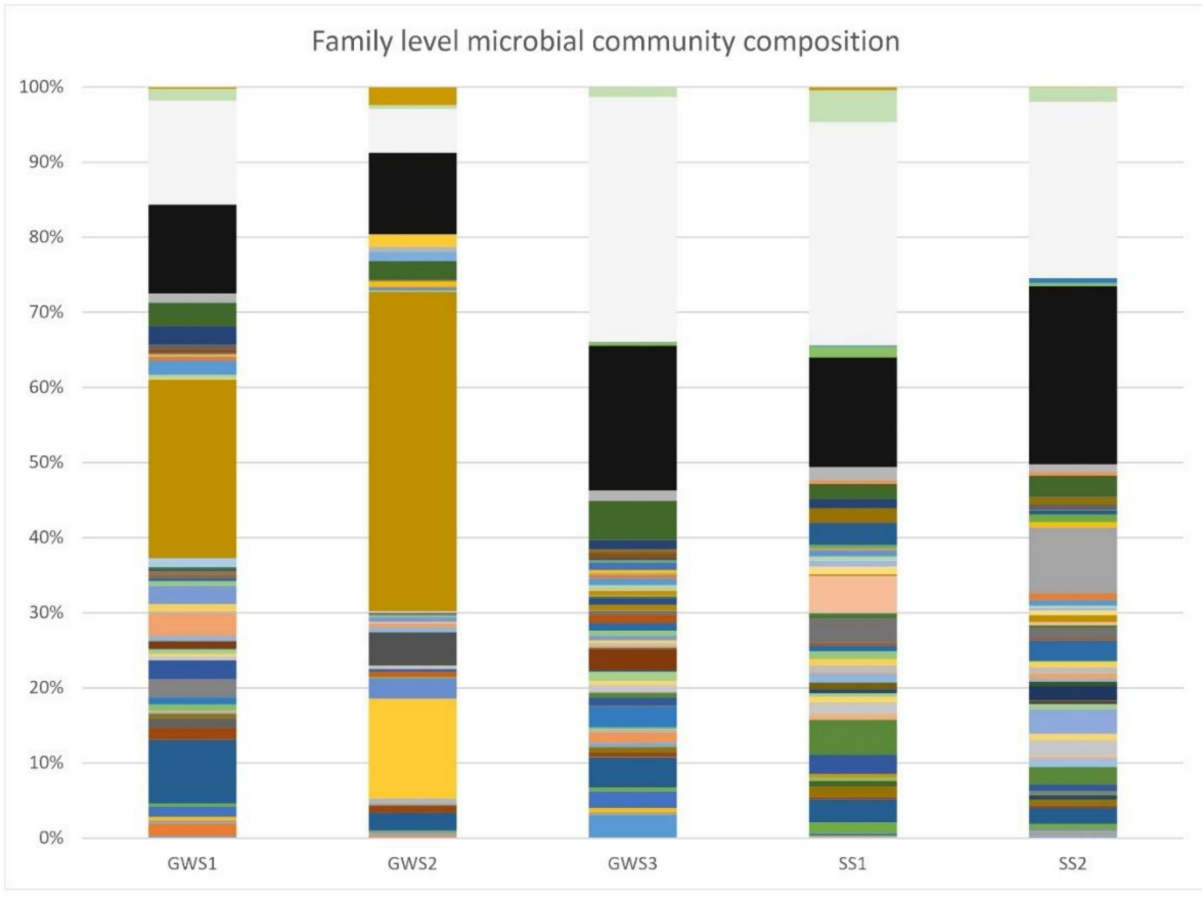

Figure 6. Family level microbial community composition in samples collected from groundwater and soil: Unclassified bacterial families are reported in light grey. Taxa with relative abundance below $0.5 \%$ are reported in black. The remaining colours indicate identified bacterial families.

When analyzing the groundwater microbial communities at the genus level (Figure 7), it emerged that Pseudomonas reached the highest percentages in GWS1 (23.76\%) and GWS2 (42.49\%) samples whereas its relative abundance in GWS3 was only $0.58 \%$. The results suggested the existence of different bacterial communities within the saturated zone intercepted by P1, from the hydraulic head (GWS1) to the well bottom (GWS2), in terms of abundance and presence of the various taxa. Most of the genera detected at the highest percentages in GWS1 were also found in GWS2 but with lower values. In addition to Pseudomonas, GWS1 microbial community was also characterized by the Kocuria [38], Sphingomonas [39] Massilia [40], Flavobacterium [41], and Rahnella [42] genera, including aerobic or facultative anaerobic, mainly mesophilic and psychrophilic, species. 
On the other hand, other genera detected in GWS2 were Stenotrophomonas [43], Sphingomonas [39], Staphylococcus [44], Desulfatitalea [45], and Desulfovibrio [46], including mesophilic, psychrotolerant, halophilic or halotolerant, and sulfate-reducing bacteria.

Microbial community of the groundwater sample GWS3 (collected at the well bottom of the piezometer P2) was mainly composed by unclassified microorganisms of the Saccharimonadales order $(12.28 \%)$ and the genera Sphingomonas [39], Sulfurifustis [47], and Legionella [48].

The top four genera in soil samples were Gaiella (4.57\%), Microlunatus (4.14\%), unclassified microorganisms of the subgroup 6 class (8.61\%) (Acidobacteria phylum), and unclassified microorganisms of the Gaiellales order (4.13\%) in SS1 and Roseovarius (5.55\%), Halomonas (3.21\%), Sphingomonas (2.69\%), and unclassified microorganisms of the subgroup 6 class (3.46\%) in SS2.

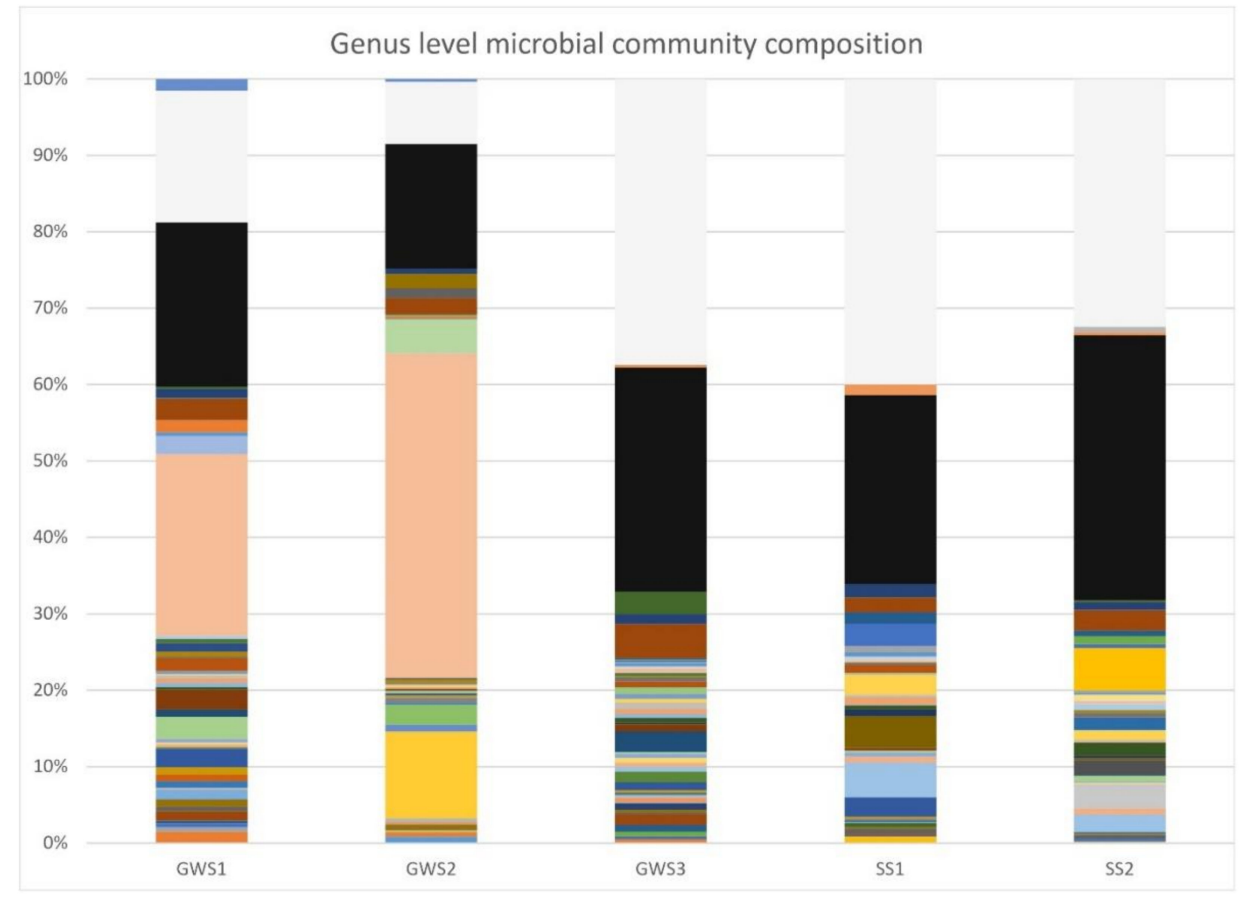

Figure 7. Genus level microbial community composition in samples collected from groundwater and soil: Unclassified bacterial genera are reported in light grey. Taxa with relative abundance below $0.5 \%$ are reported in black. The remaining colours indicate identified bacterial genera.

In order to analyze and assess if some hydrological aspects of the low-permeability system could be revealed via the use of autochthonous microorganisms, we focused our attention on those bacterial species for which the presence in groundwater and soil samples could give an indication of local-scale specific processes.

Some of the species detected in groundwater and soil samples are reported in Table 2 . The hydraulic interconnection between the topsoil and groundwater is witnessed by the presence of several species in GWS samples linked to aerobic soil environments (e.g., Pseudomonas frederiksbergensis [49]): some of them were also found in the analyzed soil samples (e.g., Pedobacter insulae [50] and Ensifer adhaerens [51]). Nitrate and nitrite reducer bacteria, such as Ensifer adhaerens [52], Devosia glacialis [53], and Afipia massiliensis [54], were detected both in soil and groundwater.

Interestingly, together with soil- and rhizo-bacteria, human pathogens belonging to the genus Legionella (L. pneumophila and L. feeleii) were discovered in some groundwater samples. These microorganisms are well known as responsible for acute human respiratory diseases (Pontiac fever or Legionnaires's disease; $[55,56])$. Their presence is, thus, of utmost importance since it testifies the possibility that Legionella cells can be transported in depth in a clayey saturated medium. 
Table 2. Physiological and biochemical characteristics of some of the species found in groundwater and soil samples after the $16 \mathrm{~S}$ rRNA gene partial sequencing. (- negative; + positive).

\begin{tabular}{|c|c|c|c|c|c|c|c|}
\hline Taxonomy & Aerobic & Facultative Anaerobic & Halophilic/Halotolerant & Nitrate Reduction & Pathogen & Samples & Citations \\
\hline Acinetobacter oleivorans & + & - & - & - & - & GWS1-2-3 & {$[57]$} \\
\hline Afipia massiliensis & + & - & - & + & - & GWS1-2 & [54] \\
\hline Deinococcus caeni & + & - & + & - & - & GWS1-2-3 & [58] \\
\hline Devosia glacialis & + & - & - & + & - & GWS1-2-3; SS1 & [53] \\
\hline Ensifer adhaerens & + & - & - & + & - & GWS1-2-3; SS1-2 & [52] \\
\hline Halomonas taeanensis & + & - & + & + & - & SS2 & [59] \\
\hline Halomonas ventosae & + & - & + & + & - & SS2 & [60] \\
\hline Janthinobacterium agaricidamnosum & + & - & - & - & - & GWS1-3; SS1 & [61] \\
\hline Legionella feeleii & + & - & - & - & + & GWS3; SS2 & {$[62]$} \\
\hline Legionella nautarum & + & - & - & + & + & GWS3 & {$[63]$} \\
\hline Legionella pneumophila & + & - & - & - & + & GWS3 & [64] \\
\hline Pedobacter insulae & + & - & - & - & - & GWS1-2-3; SS1 & [50] \\
\hline Pseudomonas frederiksbergensis & + & - & - & + & - & GWS1-2-3 & [49] \\
\hline Pseudomonas otitidis & + & - & + & - & + & GWS2 & [65] \\
\hline Pseudomonas psychrophila & + & - & + & + & - & GWS1-2-3; SS2 & {$[66]$} \\
\hline Pseudomonas xanthomarina & + & - & + & + & - & GWS2 & [67] \\
\hline Sphingomonas yunnanensis & + & - & - & + & - & GWS1-2-3; SS1-2 & [39] \\
\hline Staphylococcus warneri & + & + & + & - & + & GWS2-3 & [44] \\
\hline Stenotrophomonas chelatiphaga & + & - & - & - & - & GWS1-2; SS1 & [43] \\
\hline Streptomyces vinaceusdrappus & + & - & + & + & - & GWS1-2-3; SS1-2 & [68] \\
\hline Streptomyces xinghaiensis & + & - & + & - & - & GWS1-2-3; SS1-2 & [69] \\
\hline Thiohalobacter thiocyanaticus & + & - & + & - & - & SS2 & [70] \\
\hline
\end{tabular}




\section{Discussion and Conclusions}

During the observation period, the hydraulic head measurements, compared with local precipitations, suggested rapid water percolation from the ground surface to the saturated zone. The mixing between lower-salinity fresh-infiltration waters and higher-salinity groundwater during recharge was further confirmed through the EC vertical profiles reconstructed in P1 and P2, which clearly showed the existence of a halocline.

The percolation of fresh-infiltration waters was also a driver for the transport of microorganisms from the topsoil to the groundwater, as demonstrated by the presence of soil and rhizosphere bacterial species detected in GWS samples. The migration of cells within the clayey unsaturated medium is in agreement with the hypothesis made by Remelli et al. [25] that revealed how, at the study site, both the effective porosity and the permeability of the upper medium were increased by arthropods such as Poduromorpha, Oribatida, Coleoptera, and Hymenoptera because of their ability to create macropore (mm in dimension) networks. However, since arthropods can increase porosity and permeability in several tens of centimeters below ground and the groundwater surface was some meters deep during the observation period, we believe that other features/processes, such as drying cracks and/or rock weathering, could increase porosity and pore size within a thicker subsurface horizon.

The presence of soil- and rhizo-bacteria in groundwater samples taken at different depths further suggests that the pore network within the saturated zone should be partially but diffusely characterized by pore size greater than a few $\mu \mathrm{m}$ (>bacterial cells dimension). This result, obtained at the basin scale, is in agreement with the findings obtained by several authors at a laboratory scale when characterizing the pore diameters in clay-rich media. The porosity of clay minerals is related to the presence of broken edges on the surface of the clay particles, irregularities and voids created by the overlap of the structural packages, and voids in the interlayer sites. Pore size can vary from micropores $(<0.002 \mu \mathrm{m}$ diameter $)$ to mesopores (0.002-0.05 $\mu \mathrm{m}$ diameter). Aggregation of clay particles forms pores $>0.1 \mu \mathrm{m}$ (macropores). The pore size depends on the intrinsic properties of the clay minerals, such as layer charge and exchangeable cation [71]. The greatest effects on porosity are due to clay minerals with a greater surface area: therefore smaller size (such as illite and smectites) and expandability (smectites). In particular, clays containing mixed layers illite-smectite (or montmorillonite) show various types of pore structures, with sizes from $0.003 \mu \mathrm{m}$, characteristic of montmorillonite (due to the overlapping of elementary unit cells), to $0.02-0.1 \mu \mathrm{m}$ for the stacking of structural units (illite and montmorillonite) [72]. Therefore, micropores/fine mesopores occurring in our soils are related to the abundance of illite-montmorillonite mixed layers in the clayey portion. In swelling clay minerals, the size of the exchangeable cation has an important effect on the surface area and, therefore, on the volume of available pores. In the case of $\mathrm{Ca}^{2+}$ cations, as in our case, the contribution of the pore volume on the total volume is in the order of $45-50 \%$ [71]. Moreover, the porosity of clay soils is influenced not only by the content and type of clay minerals but also by the water regime and the presence of organic matter [73]. When a swelling mineral such as montmorillonite comes into contact with water, its volume increase is instantaneous [74]. It can drastically influence and change the soil porosity and permeability. The bacteria, in turn, can interact with the clay minerals and can alter their features (layer charge, cation exchange capacity, and exchangeable cations), modifying their swelling properties [75]. The iron reduction induced by bacteria can decrease the specific surface area of smectite by about $30 \%$ and of montmorillonite by almost 50\% (depending on the interlayer cation), inducing a loss of clay swelling; the interparticle association assumes a more compact fabric. Furthermore, the activity of organic matter intercalated in the interlayer of the smectite structure has a strong catalytic effect on the smectite-to-illite reaction which can occur at room temperature, 1 atmosphere, and in a very short time and is less effective at alkaline $\mathrm{pH}$ ([75] and references therein). Bacteria can also promote the adhesion of the clay platelets to their cells favoring the aggregate formation, and their organic secretion penetrates the surrounding clay pores and modifies the clay shrinkage/swelling behavior [76].

On the whole, the coexistence of micro-, meso-, and macropores leads to a nonuniform path within the clayey medium, and the migration of bacterial cells could be concentrated in some 
sub-volumes [77-79]. As a consequence, different degrees of retention can be identified at the core scale, therefore emphasizing the importance of studying such phenomena at the basin scale.

In a wide context, the transport of bacterial cells from the topsoil to the groundwater through a clay-rich horizon opens two opposing scenarios. Firstly, some bacterial species detected in both soil and groundwater are denitrifying or nitrate-reducing microorganisms. From a broader perspective, the "permeability" of clay-rich media could allow the transport of these kinds of microorganisms from the topsoil to the groundwater also in confined or semi-confined aquifers and, thus, could enhance denitrification and/or nitrate-reduction processes within the underlying saturated zone. These findings could be of the utmost importance when studying the evolution of nitrate contamination over space and time in those areas where agricultural, industrial, and civil activities have significantly increased the levels of reactive nitrogen $(\mathrm{N})$ in water bodies [80,81]. In fact, in many cases, $\mathrm{N}$ input sources (both organic and synthetic fertilizers) exceed crops' $\mathrm{N}$ requirements and fertilization plans seldom consider mineralization rates and factors regulating $\mathrm{N}$ dynamics in agricultural land [82-84]. As a result, nitrogen surplus is often observed, with a high impact on ecosystems, including groundwater pollution and eutrophication [85-87]. On the other hand, the same findings lead to the awareness that groundwater vulnerability of confined or semi-confined aquifers against contamination (both chemical and microbiological) could be higher than expected. In this specific context, the retrieval of DNA sequences of known human pathogens, such as the Legionella species, draw serious concerns and, in a broader perspective, sets the stage for further analyses aimed at 1) specifically evaluating the transport dynamics of these microorganisms through the soil and 2) assessing their viability over time and space in order to prevent water-related infectious diseases.

Author Contributions: Conceptualization, E.P., A.B., A.M.S., and F.C.; formal analysis, P.R.; investigation, P.R., M.R., and A.Q.; supervision, E.P., A.B., A.M.S., and F.C.; validation, P.R.; visualization, P.R.; writing—original draft, P.R., E.P., and A.B.; writing - review and editing, P.R., E.P., A.B., E.S.-M., A.C., A.M.S., and F.C. All authors have read and agreed to the published version of the manuscript.

Funding: This research received no external funding.

Acknowledgments: This work has benefited from the equipment and framework of the COMP-HUB Initiative, funded by the "Departments of Excellence" program of the Italian Ministry for Education, University, and Research (MIUR, 2018-2022). We are grateful to the reviewers for their constructive comments and valuable suggestions.

Conflicts of Interest: The authors declare no conflict of interest.

\section{References}

1. Tufenkji, N.; Emelko, M.B. Fate and transport of microbial contaminants in groundwater. In Encyclopedia of Environmental Health; Nriagu, J.O., Ed.; Elsevier: Amsterdam, The Netherlands, 2011; pp. 715-726.

2. Bucci, A.; Petrella, E.; Celico, F.; Naclerio, G. Use of molecular approaches in hydrogeological studies: The case of carbonate aquifers in southern Italy. Hydrogeol. J. 2017, 25, 1017-1031. [CrossRef]

3. Mills, A.L.; Herman, J.S.; Hornberger, G.M.; Dejesus, T.H. Effect of solution ionic-strength and iron coatings on mineral grains on the sorption of bacterial-cells to quartz sand. Appl. Environ. Microbiol. 1994, 60, 3300-3306. [CrossRef] [PubMed]

4. Mccaulou, D.R.; Bales, R.C.; Arnold, R.G. Effect of temperature-controlled motility on transport of bacteria and microspheres through saturated sediment. Water Resour. Res. 1995, 31, 271-280. [CrossRef]

5. Hendry, M.J.; Lawrence, J.R.; Maloszewski, P. Effects of velocity on the transport of two bacteria through saturated sand. Ground Water 1999, 37, 103-112. [CrossRef]

6. Yee, N.; Fein, J.B.; Daughney, C.J. Experimental study of the pH, ionic strength, and reversibility behavior of bacteria-mineral adsorption. Geochim. Cosmochim. Acta 2000, 64, 609-617. [CrossRef]

7. Dong, H.L.; Onstott, T.C.; Deflaun, M.F.; Fuller, M.E.; Scheibe, T.D.; Streger, S.H.; Rothmel, R.K.; Mailloux, B.J. Relative dominance of physical versus chemical effects on the transport of adhesion-deficient bacteria in intact cores from South Oyster, Virginia. Environ. Sci. Technol. 2002, 36, 891-900. [CrossRef]

8. Bradford, S.A.; Šimůnek, J.; Walker, S.L. Transport and straining of E. coli O157: H7 in saturated porous media. Water Resour. Res. 2006, 42. [CrossRef] 
9. Chen, G.X.; Walker, S.L. Role of solution chemistry and ion valence on the adhesion kinetics of groundwater and marine bacteria. Langmuir 2007, 23, 7162-7169. [CrossRef]

10. Ochiai, N.; Kraft, E.L.; Selker, J.S. Methods for colloid transport visualization in pore networks. Water Resour. Res. 2006, 42. [CrossRef]

11. Streit, W.R.; Schmitz, R.A. Metagenomics-The key to the uncultured microbes. Curr. Opin. Microbiol. 2004, 7, 492-498. [CrossRef]

12. Kucharzyk, K.H.; Rectanus, H.V.; Bartling, C.M.; Rosansky, S.; Minard-Smith, A.; Mullins, L.A.; Neil, K. Use of omic tools to assess methyl tert-butyl ether (MTBE) degradation in groundwater. J. Hazard. Mater. 2019, 378, 120618. [CrossRef] [PubMed]

13. Mosaddeghi, M.R.; Mahboubi, A.A.; Zandsalimi, S.; Unc, A. Influence of organic waste type and soil structure on the bacterial filtration rates in unsaturated intact soil columns. J. Environ. Manag. 2009, 90, 730-739. [CrossRef] [PubMed]

14. Naclerio, G.; Fardella, G.; Marzullo, G.; Celico, F. Filtration of Bacillus subtilis and Bacillus cereus spores in a pyroclastic topsoil, carbonate Apennines, southern Italy. Colloids Surf. B Biointerfaces 2009, 70, 25-28. [CrossRef] [PubMed]

15. Safadoust, A.; Mahboubi, A.A.; Mosaddeghi, M.R.; Gharabaghi, B.; Voroney, P.; Unc, A.; Khodakaramian, G. Significance of physical weathering of two-texturally different soils for the saturated transport of Escherichia coli and bromide. J. Environ. Manag. 2012, 107, 147-158. [CrossRef]

16. Moradi, A.; Mosaddeghi, M.R.; Chavoshi, E.; Safadoust, A.; Soleimani, M. Effect of Crude Oil-Induced Water Repellency on Transport of Escherichia coli and Bromide Through Repacked and Physically-Weathered Soil Columns. Environ. Pollut. 2019, 255, 113230. [CrossRef]

17. Boschetti, T.; Falasca, A.; Bucci, A.; De Felice, V.; Naclerio, G.; Celico, F. Influence of soil on groundwater geochemistry in a carbonate aquifer, southern Italy. Int. J. Speleol. 2014, 43, 79-94. [CrossRef]

18. Bucci, A.; Allocca, V.; Naclerio, G.; Capobianco, G.; Divino, F.; Fiorillo, F.; Celico, F. Winter survival of microbial contaminants in soil: An in situ verification. J. Environ. Sci. 2015, 27, 131-138. [CrossRef]

19. Rizzo, P.; Bucci, A.; Sanangelantoni, A.M.; Iacumin, P.; Celico, F. Coupled Microbiological-Isotopic Approach for Studying Hydrodynamics in Deep Reservoirs: The Case of the Val d'Agri Oilfield (Southern Italy). Water 2020, 12, 1483. [CrossRef]

20. Bucci, A.; Petrella, E.; Naclerio, G.; Gambatese, S.; Celico, F. Bacterial migration through low-permeability fault zones in compartmentalised aquifer systems: A case study in Southern Italy. Int. J. Speleol. 2014, 43, 273-281. [CrossRef]

21. Bucci, A.; Petrella, E.; Naclerio, G.; Allocca, V.; Celico, F. Microorganisms as contaminants and natural tracers: A 10-year research in some carbonate aquifers (southern Italy). Environ. Earth Sci. 2015, 74, 173-184. [CrossRef]

22. Bucci, A.; Naclerio, G.; Allocca, V.; Celico, P.; Celico, F. Potential use of microbial community investigations to analyze hydrothermal systems behaviour: The case of Ischia island, southern Italy. Hydrol. Process. 2011, 25, 1866-1873. [CrossRef]

23. Hernandez-Diaz, R.; Petrella, E.; Bucci, A.; Naclerio, G.; Feo, A.; Sferra, G.; Chelli, A.; Zanini, A.; Gonzales-Hernandez, P.; Celico, F. Integrating hydrogeological and microbiological data and modelling to characterize the hydraulic features and behavior of coastal carbonate aquifers: A case in Western Cuba. Water 2019, 11, 1989. [CrossRef]

24. Vescovi, P.; Andreozzi, M.; De Nardo, M.T.; Lasagna, S.; Martelli, L.; Rio, D.; Tellini, C.; Vernia, L. Note illustrative della carta geologica d'Italia alla scala 1:50,000, foglio 216, Borgo Val di Taro. In Presidenza del Consigio dei Ministri, Servizio Geologico d'Italia, Regione Emilia-Romagna; S.El.Ca. SRLS.El.Ca. SRL: Florence, Italy, 2002.

25. Remelli, S.; Petrella, E.; Chelli, A.; Conti, F.D.; Lozano Fondon, C.; Celico, F.; Francese, R.; Menta, C. Hydrodynamic and soil biodiversity characterization in an active landslide. Water 2019, 11, 1882. [CrossRef]

26. Frouz, J. Use of soil dwelling Diptera (Insecta, Diptera) as bioindicators: A review of ecological requirements and response to disturbance. Agric. Ecosyst. Environ. 1999, 74, 167-186. [CrossRef]

27. Edwards, C.A. The ecology of Symphyla. Entomol. Exp. Appl. 1958, 1, 308-319. [CrossRef]

28. Menta, C.; Leoni, A.; Gardi, C.; Conti, F. Are grasslands important habitats for soil microarthropod conservation? Biodivers. Conserv. 2011, 20, 1073-1087. [CrossRef] 
29. Geoportale. Base Map: Technical Regional Map 1:5000, Emilia-Romagna Region 1998 (ed.). Available online: https://geoportale.regione.emilia-romagna (accessed on 23 June 2020).

30. Morin, R.H.; Carleton, G.B.; Poirier, S. Fractured-aquifer hydrogeology from geophysical logs; the passaic formation, New Jersey. Ground Water 1997, 35, 328-338. [CrossRef]

31. Cook, P.G.; Love, A.J.; Dighton, J.C. Inferring ground water flow in fractured rock from dissolved radon. Ground Water 1999, 37, 606-610. [CrossRef]

32. Aquino, D.; Petrella, E.; Florio, M.; Celico, P.; Celico, F. Complex hydraulic interactions between compartmentalized carbonate aquifers and heterogeneous siliciclastic successions: A case study in southern Italy. Hydrol. Process. 2015, 29, 4252-4263. [CrossRef]

33. Milani, C.; Hevia, A.; Foroni, E.; Duranti, S.; Turroni, F.; Lugli, G.A.; Sanchez, B.; Martín, R.; Gueimonde, M.; Van Sinderen, D.; et al. Assessing the fecal microbiota: An optimised ion torrent 16S rRNA gene-based analysis protocol. PLoS ONE 2013, 8, e68739. [CrossRef]

34. Caporaso, J.G.; Kuczynski, J.; Stombaugh, J.; Bittinger, K.; Bushman, F.D.; Costello, E.K.; Fierer, N.; Gonzalez Peña, A.; Goodrich, J.K.; Gordon, J.I.; et al. QIIME allows analysis of high-throughput community sequencing data. Nat. Methods 2010, 7, 335-336. [CrossRef] [PubMed]

35. Callahan, B.J.; McMurdie, P.J.; Rosen, M.J.; Han, A.W.; Johnson, A.J.; Holmes, S.P. DADA2: High-resolution sample inference from Illumina amplicon data. Nat. Methods 2016, 13, 581-583. [CrossRef] [PubMed]

36. Bokulich, N.A.; Kaehler, B.D.; Rideout, J.R.; Dillon, M.; Bolyen, E.; Knight, R.; Huttley, G.A.; Caporaso, J.G. Optimizing taxonomic classification of marker-gene amplicon sequences with QIIME 2's q2-feature-classifier plugin. Microbiome 2018, 6, 90. [CrossRef] [PubMed]

37. Quast, C.; Pruesse, E.; Yilmaz, P.; Gerken, J.; Schweer, T.; Yarza, P.; Peplies, J.; Glöckner, F.O. The SILVA ribosomal RNA gene database project: Improved data processing and web-based tools. Nucleic Acids Res. 2012, 41, D590-D596. [CrossRef] [PubMed]

38. Stackebrandt, E.; Koch, C.; Gvozdiak, O.; Schumann, P. Taxonomic Dissection of the Genus Micrococcus: Kocuria gen. nov., Nesterenkonia gen. nov., Kytococcus gen. nov., Dermacoccus gen. nov., and Micrococcus Cohn 1872 gen. emend. Int. J. Syst. Bacteriol. 1995, 45, 682-692. [CrossRef]

39. Zhang, Y.Q.; Chen, Y.G.; Li, W.J.; Tian, X.P.; Xu, L.H.; Jiang, C.L. Sphingomonas yunnanensis sp. nov., a novel Gram-negative bacterium from a contaminated plate. Int. J. Syst. Evol. Microbiol. 2005, 55, 2361-2364. [CrossRef]

40. Baldani, J.I.; Rouws, L.; Cruz, L.M.; Olivares, F.L.; Schmid, M.; Hartmann, A. The family Oxalobacteraceae. In The Prokaryotes; Rosenberg, E., DeLong, E.F., Lory, S., Stackebrandt, E., Thompson, F., Eds.; Springer: Berlin/Heidelberg, Germany, 2014; pp. 919-974.

41. Bernardet, J.F.; Bowman, J.P. The genus Flavobacterium. In The Prokaryotes; Dworkin, M., Falkow, S., Rosenberg, E., Schleifer, K.H., Stackebrandt, E., Eds.; Springer: New York, NY, USA, 2006; pp. 481-531.

42. Berge, O.; Heulin, T.; Achouak, W.; Richard, C.; Bally, R.; Balandreau, J. Rahnella aquatilis, a nitrogen-fixing enteric bacterium associated with the rhizosphere of wheat and maize. Can. J. Microbiol. 1991, 37, 195-203. [CrossRef]

43. Kaparullina, E.; Doronina, N.; Chistyakova, T.; Trotsenko, Y. Stenotrophomonas chelatiphaga sp. nov., a new aerobic EDTA-degrading bacterium. Syst. Appl. Microbiol. 2009, 32, 157-162. [CrossRef]

44. Kloos, W.E.; Schleifer, K.H. Isolation and characterization of staphylococci from human skin II. descriptions of four new species: Staphylococcus warneri, Staphylococcus capitis, Staphylococcus hominis, and Staphylococcus simulans1. Int. J. Syst. Evol. Microbiol. 1975, 25, 62-79. [CrossRef]

45. Higashioka, Y.; Kojima, H.; Watanabe, M.; Fukui, M. Desulfatitalea tepidiphila gen. nov., sp. nov., a sulfate-reducing bacterium isolated from tidal flat sediment. Int. J. Syst. Evol. Microbiol. 2013, 63, 761-765. [CrossRef]

46. Fauque, G.D. Ecology of sulfate-reducing bacteria. In Sulfate-Reducing Bacteria; Barton, L.L., Ed.; Springer: Boston, MA, USA, 1995; Volume 8, pp. 217-241.

47. Kojima, H.; Shinohara, A.; Fukui, M. Sulfurifustis variabilis gen. nov., sp nov., a sulfur oxidizer isolated from a lake, and proposal of Acidiferrobacteraceae fam. nov and Acidiferrobacterales ord. nov. Int. J. Syst. Evol. Microbiol. 2015, 65, 3709-3713. [CrossRef] [PubMed]

48. Kao, P.M.; Tung, M.C.; Hsu, B.M.; Chiu, Y.C.; She, C.Y.; Shen, S.M.; Huang, Y.L.; Huang, W.C. Identification and quantitative detection of Legionella spp. in various aquatic environments by real-time PCR assay. Environ. Sci. Pollut. Res. Int. 2013, 20, 6128-6137. [CrossRef] [PubMed] 
49. Andersen, S.M.; Johnsen, K.; Sorensen, J.; Nielsen, P.; Jacobsen, C.S. Pseudomonas frederiksbergensis sp. nov., isolated from soil at a coal gasification site. Int. J. Syst. Evol. Microbiol. 2000, 50, 1957-1964. [CrossRef] [PubMed]

50. Yoon, J.H.; Kang, S.J.; Oh, H.W.; Oh, T.K. Pedobacter insulae sp. nov., isolated from soil. Int. J. Syst. Evol. Microbiol. 2007, 57, 1999-2003. [CrossRef]

51. Rogel, M.A.; Hernandez-Lucas, I.; Kuykendall, L.D.; Balkwill, D.L.; Martinez-Romero, E. Nitrogen-fixing nodules with Ensifer adhaerens harboring Rhizobium tropici symbiotic plasmids. Appl. Environ. Microbiol. 2001, 67, 3264-3268. [CrossRef]

52. Casida, L.E. Ensifer adhaerens gen. nov., sp. nov.: A bacterial predator of bacteria in soil. Int. J. Syst. Bacteriol. 1982, 32, 339-345. [CrossRef]

53. Zhang, D.C.; Redzic, M.; Liu, H.C.; Zhou, Y.G.; Schinner, F.; Margesin, R. Devosia psychrophile sp. nov. and Devosia glacialis sp. nov., from alpine glacier cryoconite, and an emended description of the genus Devosia. Int. J. Syst. Evol. Microbiol. 2012, 62, 710-715. [CrossRef]

54. La Scola, B.; Mallet, M.N.; Grimont, P.A.D.; Raoult, D. Description of Afipia birgiae sp. nov. and Afipia massiliensis sp. nov. and recognition of Afipia felis genospecies A. Int. J. Syst. Evol. Microbiol. 2002, 52, 1773-1782.

55. Newton, H.J.; Ang, D.K.Y.; Van Driel, I.R.; Hartland, E. Molecular pathogenesis of infections caused by Legionella pneumophila. Clin. Microbiol. Rev. 2010, 23, 274-298. [CrossRef]

56. Wang, C.; Chuai, X.; Liang, M. Legionella feeleii: Pneumonia or Pontiac fever? Bacterial virulence traits and host immune response. Med. Microbiol. Immunol. 2019, 208, 25-32. [CrossRef]

57. Kang, Y.S.; Jung, J.; Jeon, C.O.; Park, W. Acinetobacter oleivorans sp. nov. is capable of adhering to and growing on diesel-oil. J. Microbiol. 2011, 49, 29-34. [CrossRef] [PubMed]

58. Im, W.T.; Jung, H.M.; Ten, L.N.; Kim, M.K.; Bora, N.; Goodfellow, M.; Lim, S.; Jung, J.; Lee, S.T. Deinococcus aquaticus sp. nov., isolated from fresh water, and Deinococcus caeni sp. nov., isolated from activated sludge. Int. J. Syst. Evol. Microbiol. 2008, 58, 2348-2353. [CrossRef] [PubMed]

59. Lee, J.C.; Jeon, C.O.; Lim, J.M.; Lee, S.M.; Lee, J.M.; Song, S.M.; Park, D.J.; Li, W.J.; Kim, C.J. Halomonas taeanensis sp. nov., a novel moderately halophilic bacterium isolated from a solar saltern in Korea. Int. J. Syst. Evol. Microbiol. 2005, 55, 2027-2032. [CrossRef] [PubMed]

60. Martínez-Cánovas, M.J.; Quesada, E.; Llamas, I.; Bejar, V. Halomonas ventosae sp. nov., a moderately halophilic, denitrifying, exopolysaccharide-producing bacterium. Int. J. Syst. Evol. Microbiol. 2004, 54, $733-737$. [CrossRef] [PubMed]

61. Lincoln, S.P.; Fermor, T.R.; Tindall, B.J. Janthinobacterium agaricidamnosum sp. nov., a soft rot pathogen of Agaricus bisporus. Int. J. Syst. Evol. Microbiol. 1999, 49, 1577-1589. [CrossRef] [PubMed]

62. Herwaldt, L.A.; Gorman, G.W.; McGrath, T.; Toma, S.; Brake, B.; Hightower, A.W.; Jones, J.; Reingold, A.L.; Boxer, P.A.; Tang, P.W. A new Legionella species, Legionella feeleii species nova, causes Pontiac fever in an automobile plant. Ann. Intern. Med. 1984, 100, 333-338. [CrossRef]

63. Dennis, P.J.; Brenner, D.J.; Thacker, W.L.; Wait, R.; Vesey, G.; Steigerwalt, A.G.; Benson, R.F. Five new Legionella species isolated from water. Int. J. Syst. Evol. Microbiol. 1993, 43, 329-337. [CrossRef]

64. Orrison, L.H.; Cherry, W.B.; Fliermans, C.B.; Dees, S.B.; McDougal, L.K.; Dodd, D.J. Characteristics of environmental isolates of Legionella pneumophila. Appl. Environ. Microbiol. 1981, 42, 109-115. [CrossRef]

65. Clark, L.L.; Dajcs, J.J.; McLean, C.H.; Bartell, J.G.; Stroman, D.W. Pseudomonas otitidis sp. nov., isolated from patients with otic infections. Int. J. Syst. Evol. Microbiol. 2006, 56, 709-714. [CrossRef]

66. Yumoto, I.; Kusano, T.; Shingyo, T.; Nodasaka, Y.; Matsuyama, H.; Okuyama, H. Assignment of Pseudomonas sp. strain E-3 to Pseudomonas psychrophila sp. nov., a new facultatively psychrophilic bacterium. Extremophiles 2001, 5, 343-349. [CrossRef]

67. Romanenko, L.A.; Uchino, M.; Falsen, E.; Lysenko, A.M.; Zhukova, N.V.; Mikhailov, V.V. Pseudomonas xanthomarina sp. nov., a novel bacterium isolated from marine ascidian. J. Gen. Appl. Microbiol. 2005, 51, 65-71. [CrossRef]

68. Yandigeri, M.S.; Malviya, N.; Solanki, M.K.; Shrivastava, P.; Sivakumar, G. Chitinolytic Streptomyces vinaceusdrappus S5MW2 isolated from Chilika lake, India enhances plant growth and biocontrol efficacy through chitin supplementation against Rhizoctonia solani. World J. Microbiol. Biotechnol. 2015, 31, 1217-1225. [CrossRef] 
69. Zhao, X.Q.; Li, W.J.; Jiao, W.C.; Li, Y.; Yuan, W.J.; Zhang, Y.Q.; Klenk, H.P.; Suh, J.W.; Bai, F.W. Streptomyces xinghaiensis sp. nov., isolated from marine sediment. Int. J. Syst. Evol. Microbiol. 2009, 59, 2870-2874. [CrossRef]

70. Sorokin, D.Y.; Kovaleva, O.L.; Tourova, T.P.; Muyzer, G. Thiohalobacter thiocyanaticus gen. nov., sp. nov., a moderately halophilic, sulfur-oxidizing gammaproteobacterium from hypersaline lakes, that utilizes thiocyanate. Int. J. Syst. Evol. Microbiol. 2010, 60, 444-450. [CrossRef]

71. Rutherford, D.W.; Chiou, C.T.; Eberl, D.D. Effects of exchanged cation on the microporosity of montmorillonite. Clays Clay Miner. 1997, 45, 534-543. [CrossRef]

72. Kuila, U.; Prasad, M. Specific surface area and pore-size distribution in clays and shales. Geophys. Prospect. 2013, 61, 341-362. [CrossRef]

73. Zaffar, M.; Lu, S.-G. Pore size distribution of clayey soils and its correlation with soil organic matter. Pedosphere 2015, 25, 240-249. [CrossRef]

74. Aksu, I.; Bazilevskaya, E.; Karpyn, Z.T. Swelling of clay minerals in unconsolidated porous media and its impact on permeability. GeoResJ 2015, 7, 1-13. [CrossRef]

75. Mueller, B. Experimental interactions between clay minerals and bacteria: A review. Pedosphere 2015, 25, 799-810. [CrossRef]

76. Alimova, A.; Katz, A.; Steiner, N.; Rudolph, E.; Wei, H.; Steiner, J.C.; Gottlieb, P. Bacteria-clay interaction: Structural changes in smactite induced during biofilm formation. Clays Clay Miner. 2009, 57, $205-212$. [CrossRef]

77. Dexter, A.R. Heterogeneity of unsaturated, gravitational flow of water through beds of large particles. Water Resour. Res. 1993, 29, 1859-1862. [CrossRef]

78. Wildenschild, D.; Jensen, K.H.; Villholth, K.; Illangasekare, T.H. A laboratory analysis of the effect of macropores on solute transport. Ground Water 1994, 32, 381-389. [CrossRef]

79. McMurry, S.W.; Coyne, M.S.; Perfect, E. Fecal coliforms transport through intact soil blocks amended with poultry manure. J. Environ. Qual. 1998, 27, 86-92. [CrossRef]

80. Galloway, J.N.; Townsend, A.R.; Erisman, J.W.; Bekunda, M.; Cai, Z.; Freney, J.R.; Martinelli, L.A.; Seizinger, S.P.; Sutton, M.A. Transformation of the Nitrogen cycle: Recent trends, questions and potential solutions. Science 2008, 320, 889-892. [CrossRef]

81. Overeem, I.; Kettner, A.J.; Syvitski, J.P.M. 9.40 impacts of humans on river fluxes and morphology. In Treatise on Geomorphology; Shroder, J.F., Wohl, E., Eds.; Academic Press: Cambridge, MA, USA, 2013; pp. 828-842.

82. Sutton, M.; Howard, C.; Erisman, J.W.; Billen, G.; Bleeker, A.; Grennfelt, P.; Van Grinsven, H.; Grizzetti, B. The European Nitrogen Assessment; Cambridge University Press: Cambridge, UK, 2011.

83. Barakata, M.; Cheviron, B.; Angulo-Jaramillo, R. Influence of the irrigation technique and strategies on the nitrogen cycle and budget: A review. Agric. Water Manag. 2016, 178, 225-238. [CrossRef]

84. Racchetti, E.; Salmaso, F.; Pinardi, M.; Quadroni, S.; Soana, E.; Sacchi, E.; Severini, E.; Celico, F.; Viaroli, P.; Bartoli, M. Flood irrigation increases river-groundwater interactions and diffuse nitrate pollution in agricultural watersheds. Water 2019, 11, 2304. [CrossRef]

85. Van Grinsven, H.J.M.; Ward, M.H.; Benjamin, N.; De Kok, T.M. Does the evidence about health risks associated with nitrate ingestion warrant an increase of the nitrate standard for drinking water? Environ. Health 2006, 5, 26. [CrossRef]

86. Rivett, M.O.; Buss, S.R.; Morgan, P.; Smith, J.W.N.; Bemment, C.D. Nitrate attenuation in groundwater: A review of biogeochemical controlling processes. Water Res. 2008, 42, 4215-4232. [CrossRef]

87. Howarth, R.; Chan, F.; Conley, D.J.; Garnier, J.; Doney, S.C.; Marino, R.; Billen, G. Coupled biogeochemical cycles: Eutrophication and hypoxia in temperate estuaries and coastal marine ecosystems. Front. Ecol. Environ. 2011, 9, 18-26. [CrossRef]

(C) 2020 by the authors. Licensee MDPI, Basel, Switzerland. This article is an open access article distributed under the terms and conditions of the Creative Commons Attribution (CC BY) license (http://creativecommons.org/licenses/by/4.0/). 